\title{
ВПЛИВ СТРОКУ СІВБИ ТА СОРТОВИХ ОСОБЛИВОСТЕЙ НА ПРОДУКТИВНІСТЬ КОРІАНДРУ В УМОВАХ ПІВНІЧНОГО СТЕПУ УКРӒ̈НИ
}

\section{Г. М. Козелець}

Кіровоградська державна сільськогосподарська дослідна станція Інституту сільського господарства степової зони НААН України

Наведено узагальнені результати досліджень з вивчення впливу строків сівби та сортових особливостей на ріст, розвиток та продуктивність рослин коріандру в умовах північного Степу України. Встановлено, що в умовах північного Степу для отримання вищої продуктивності коріандру ефективним $є$ проведення сівби підзиму. За цих умов отримали урожайність 1,2 т/га, за ранньовесняного сіву - 0,86 т/га. Сорт коріандру Оксаніт забезпечив урожайність 1,12 т/га, Нектар - 1,04 т/га та Медун - 0,95 т/га.

Коріандр, продуктивність, строк сівби, сорт, иирина міжряддя, ефірна олія

У період сучасного розвитку сільського господарства та нестабільності цін на продукцію сільськогосподарського виробництва необхідно знаходити нові шляхи отримання прибутку за рахунок введення у сівозміну нових нетрадиційних культур. Однією з таких культур є коріандр, який за своїми морфолого-біологічними властивостями здатний формувати високі врожаї в умовах зони північного Степу України [1].

Коріандр - однорічна трав'яниста рослина, ефірна олія, яку добувають $з$ його плодів, є початковим продуктом для отримання ряду духмяних речовин із запахом лимона, помаранча, бергамоту, троянди, фіалки, лілії та інших, що використовуються в парфумерній промисловості для виготовлення парфумів, одеколону, туалетного мила. Широке застосування коріандр має в лікеро-горілчаній, харчовій, текстильній промисловості, у фармакології та металургії [2-4]. За останні роки значно підвищився попит на товарне насіння коріандру, яке $є$ продуктом експорту [5].

Сучасні сорти цієї культури мають високий потенційний рівень врожайності та якості плодів. Однак за останні роки середня врожайність в зоні північного Степу України знаходиться в межах 0,6-0,7 т/га. Низький рівень врожайності коріандру можна пов'язати з відсутністю розроблених елементів технології його вирощування з урахуванням особливостей грунтово-

(C) Г. М. Козелець. 2012.

ISSN 0582-5075. Селекція і насінництво. 2012. Випуск 102. 
кліматичних умов даної зони та властивостей нових сортів. Коріандр вирощується за загальноприйнятою технологією для південного Степу, проте в умовах північного Степу України він може забезпечувати врожайність в межах 2,0-2,5 т/га та високий рівень рентабельності.

Одним з шляхів збільшення виробництва насіння коріандру та ефірної олії $є$ розроблення елементів технології його вирощування з урахуванням особливостей грунтово-кліматичних умов даної зони, що сприятиме отриманню високого рівня врожайності.

Вище наведене і обумовило необхідність проведення наукових досліджень 3 вивчення впливу елементів технології вирощування на ріст, розвиток рослин коріандру та їх продуктивність.

Методика та вихідний матеріал. Дослідження проводили протягом 2007-2010 pр. у польовій сівозміні лабораторії селекції і первинного насінництва та науково-консультаційного забезпечення трансферу інновацій Кіровоградської державної сільськогосподарської дослідної станції ІСГСЗ НААН. Грунт дослідних ділянок - чорнозем звичайний середньо гумусний глибокий важкосуглинковий, який утворився в результаті дернового процесу під покривом трав'янистої рослинності в умовах недостатнього зволоження на карбонатному лесі. Вміст гумусу в орному шарі грунту $4,63 \%$, гідролізованого азоту - 12 мг на 100 г грунту, рухомих фосфору та калію - 11,6 та 11,8 мг на 100 г грунту відповідно, $\mathrm{pH}-5,4$. Вміст мікроелементу бор становить 1,0 мг; марганцю - 7,6 та цинку 0,14 мг на 100 г грунту. Сума ввібраних основ становить від 39,4 до 42,0 мг на 100 г грунту. Попередник у дослідах озима пшениця по пару. У дослідах вивчалися сорти: Оксаніт (селекція КДСГДС ІСГСЗ НААН), Нектар, Медун (сорти селекції ІЕЛР НААН).

Оксаніт - середньостиглий, вегетаційний період 100 днів. Висота рослин 115-120 см. Стійкий до вилягання. Суцвіття квітки блідорожевого кольору. Плід округлий, зі слабо виявленою ребристістю, світло-коричневого кольору. Маса 1000 насінин 7-8 г. Посухостійкий. Стійкий до осипання. Високоврожайний, урожайність до 2,6 т/га. Вміст ефірної олії 1,8-2,4\%.

Нектар - середньостиглий. Висота прикріплення нижніх зонтиків 4058 см. Квітки блідо-рожеві, плід темно-солом'яного кольору. Маса 1000 насінин 7,2 г. Високоврожайний. Урожайність 2,2-2,7 т/га. Вміст ефірної олії 2,0-2,6\%.

Медун - середньостиглий. Висота прикріплення нижніх зонтиків 48-55 см. Квітки блідо-рожеві, плід темно-солом'яного кольору. Маса 1000 насінин 7-8 г. Урожайність 2,2-2,5 т/га. Вміст ефірної олії 2,5 \%.

Після збирання попередника поле дискували грунтообробним агрегатом та проводили оранку на глибину 22-25 см. Ранньовесняний обробіток включав закриття вологи та передпосівну культивацію на глибину 4-5 см.

Сівбу проводили селекційною сівалкою СКС-6-10 та СН-10 залежно від варіантів. Норма висіву згідно варіантів. Глибина загортання 
насіння становила 2-3 см.

Площа облікової ділянки $18 \mathrm{~m}^{2}$, посівної - $36 \mathrm{~m}^{2}$. Повторність чотириразова. Досліди закладалися методом розщеплених ділянок, розміщення варіантів систематичне.

Залежно від строків сівбу проводили 1 листопада 2006 р. (підзимовий строк сівби) та 20 березня 2007 р. (ранньовесняний строк сівби); 1 листопада 2007 р. (підзимовий строк сівби) та 26 березня 2008 р. (ранньовесняний строк сівби); 2 листопада 2008 р. (підзимовий строк сівби) та 4 квітня 2009 p. (ранньовесняний строк сівби); 3 листопада 2009 р. (підзимовий строк сівби) та 1 квітня 2010 р. (ранньовесняний строк сівби).

Погодні умови вегетаційного періоду 2007 р. суттєво відрізнялися від середніх багаторічних показників надмірними температурами та тривалими періодами без опадів у критичні фази розвитку рослин коріандру. Це мало негативний вплив на продуктивність коріандру. Погодні умови періоду вегетації коріандру 2008 р. були відносно сприятливими для росту та розвитку культури. Найбільш сприятливим за режимом зволоження в основні фази росту та розвитку рослин коріандру був 2009 р.

Результати. Було встановлено, що впровадження у виробництво підзимового строку сівби коріандру - це перспективний напрямок його вирощування в північній зоні Степу України, оскільки дозволяє ефективніше використати вологу з грунту, яка накопичується протягом зимового періоду і зменшувати напругу у весняний період. При цьому вегетаційний період коріандру закінчується раніше. Метеорологічні умови в роки проведення досліджень дуже різнилися між собою, що певним чином вплинуло на врожайність коріандру.

На період сівби коріандру ранньовесняного строку рослини підзимового були в фазі повних сходів. Фазу повних сходів у рослин ранньовесняного строку сівби було відмічено з 14 по 22 квітня, залежно від умов року коли рослини підзимового вже були у фазі розетки (3-4 пари справжніх листочків).

Порівнюючи польову схожість рослин підзимового строку сівби 3 ранньовесняним слід відмітити, що польова схожість підзимового строку сівби була вища на 7-8 \% відносно ранньовесняного.

В наших дослідженнях встановлено, що елементи структури врожаю в значній мірі залежали від строків сівби.

Порівнюючи висоту рослин коріандру залежно від строків сівби відмічаємо, що рослини підзимового строку сівби були вищими на 30-35 см у порівнянні з рослинами ранньовесняного строку сівби і така тенденція спостерігалася протягом всього вегетаційного періоду.

За підзимового строку сівби висота прикріплення нижнього зонтика, кількість гілок першого порядку, продуктивних зонтиків і плодів з однієї рослини мали вищі показники на 48, 32, 44 і 24 \% відповідно у порівнянні 3 рослинами коріандру ранньовесняного (табл. 1).

Сортові особливості також мали вплив на індивідуальну продуктив- 
ність рослин коріандру, а саме сорт Оксаніт мав вищі показники кількості гілок першого порядку, продуктивних зонтиків та плодів з однієї рослини і вони в середньому по варіантах становили $8,2,13,4$ і 134,5, тоді як у сортів Нектар і Медун ці показники були нижчими і становили у сорту Нектар 6,6, 12,1 та 126,2, Медун - 7,5, 10,8 і 124,0 відповідно.

У середньому за роки досліджень маса 1000 насінин при підзимовому строкові сівби була більшою на 0,8-1,5 г у порівнянні з ранньовесняним, де вона становила 6,7 г. Також спостерігалась залежність маси 1000 насінин від ширини міжрядь. Так, у варіантах із шириною міжрядь 0,45 м вона була більшою на 0,3-0,5 г, ніж при сівбі 3 шириною міжрядь 0,15 м. Рослини сорту Оксаніт мали масу 1000 насінин в середньому за строками сівби та ширині міжрядь - 7,3 г, рослини сорту Нектар - 7,1 г, Медун - 7,4 г відповідно.

Результати досліджень свідчать, що урожайність рослин коріандру залежала від строків сівби, сортових особливостей та ширини міжрядь. Серед досліджуваних факторів найбільш позитивний вплив на рівень даного показника було виявлено у варіантах при підзимовому строкові сівби у сорту Оксаніт 3 шириною міжрядь 0,45 м - 1,35 т/га, а найменший - при ранньовесняному у сорту Медун при ширині міжрядь 0,15 м $-0,83$ т/га (табл. 2).

Погодні умови вегетаційного періоду коріандру в роки досліджень мали значний вплив на урожайність рослин. Так, у 2007 році в середньому по досліду вона становила 0,83 т/га, у 2008 р. - 1,08 т/га, а в 2009 р. - 1,19 т/га. При підзимовому строкові сівби урожайність була вищою на $30 \%$ i становила 1,21 т/га, при ранньовесняному - 0,86 т/га.

При ширині міжрядь 0,45 м отримано в середньому по варіантах 1,05 т/га, тоді як при $0,15 \mathrm{~m}-1,00$ т/га.

Результати дисперсійного аналізу свідчать, що урожайність коріандру в середньому за роки досліджень на $41,1 \%$ залежала від строку сівби, на 25,2 \% від сортових особливостей та на 18,5 \% від ширини міжрядь. Взаємодія факторів строку сівби та ширини міжрядь обумовлювала даний показник на 4,6\%, взаємодія факторів строку сівби та сортових сортових особливостей $-3,1 \%$ загальна взаємодія факторів мала такий показник $-2,5 \%$.

У переважній більшості плоди коріандру використовують як сировину для добування ефірної олії. Основною складовою частиною коріандрової ефірної олії є спирт - линалоол, вміст якого буває від 50 до 85 \%. Тому, великий акцент в наших дослідженнях ставиться не лише на підвищення врожайності плодів коріандру, а й на вміст в них ефірної олії, що в цілому матиме позитивний вплив на збір ефірної олії з одиниці площі.

Аналізуючи масову частку ефірної олії в плодах коріандру залежно від досліджуваних факторів встановлено, що погодні умови років проведення досліджень мали вагомий вплив на даний показник. А саме в умовах 2007 року масова частка ефірної олії в середньому становила $1,62 \%$, у 2008 р. - 1,27 \%, у 2009 р. $-1,22 \%$ (табл. 3). 


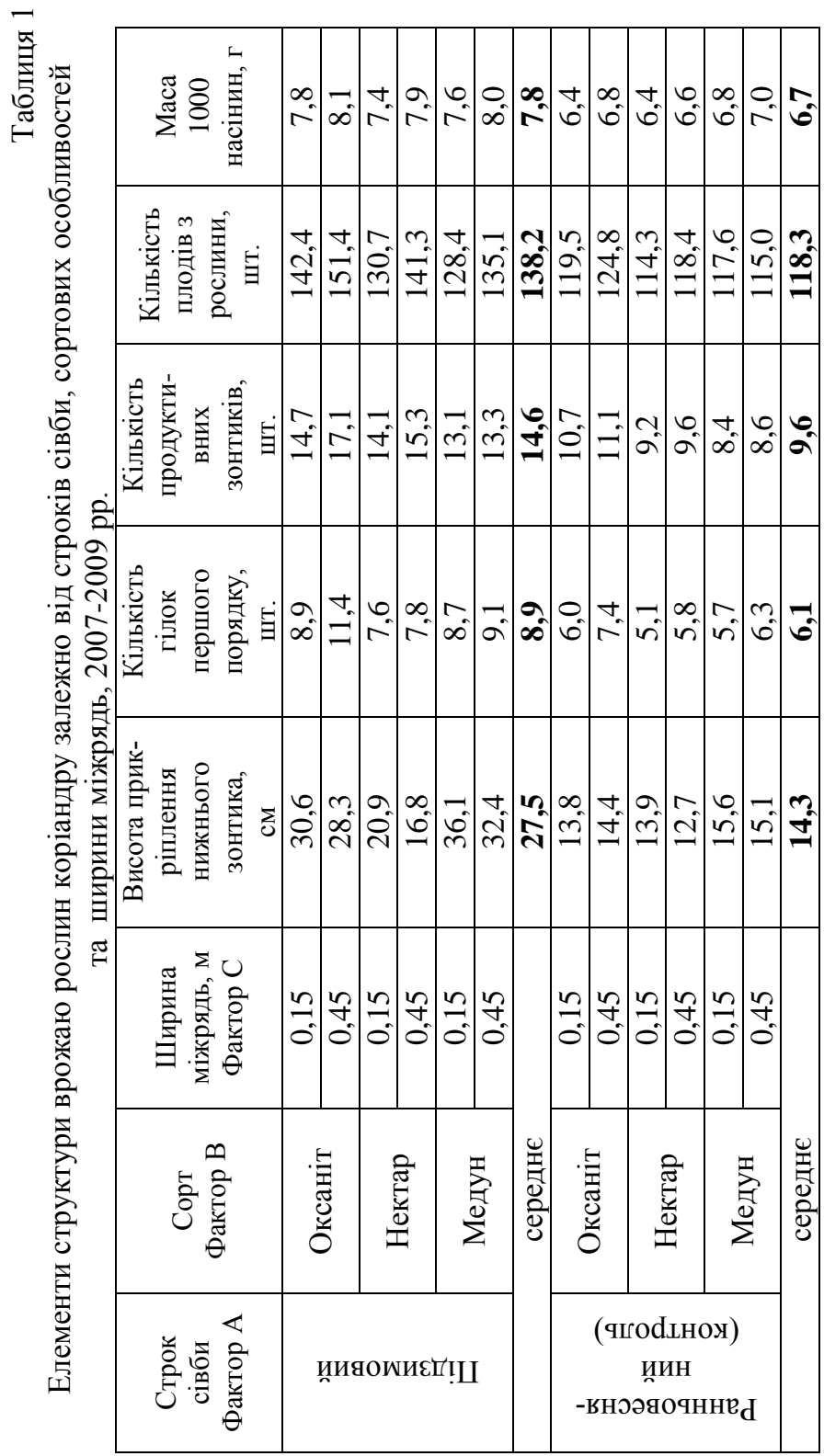




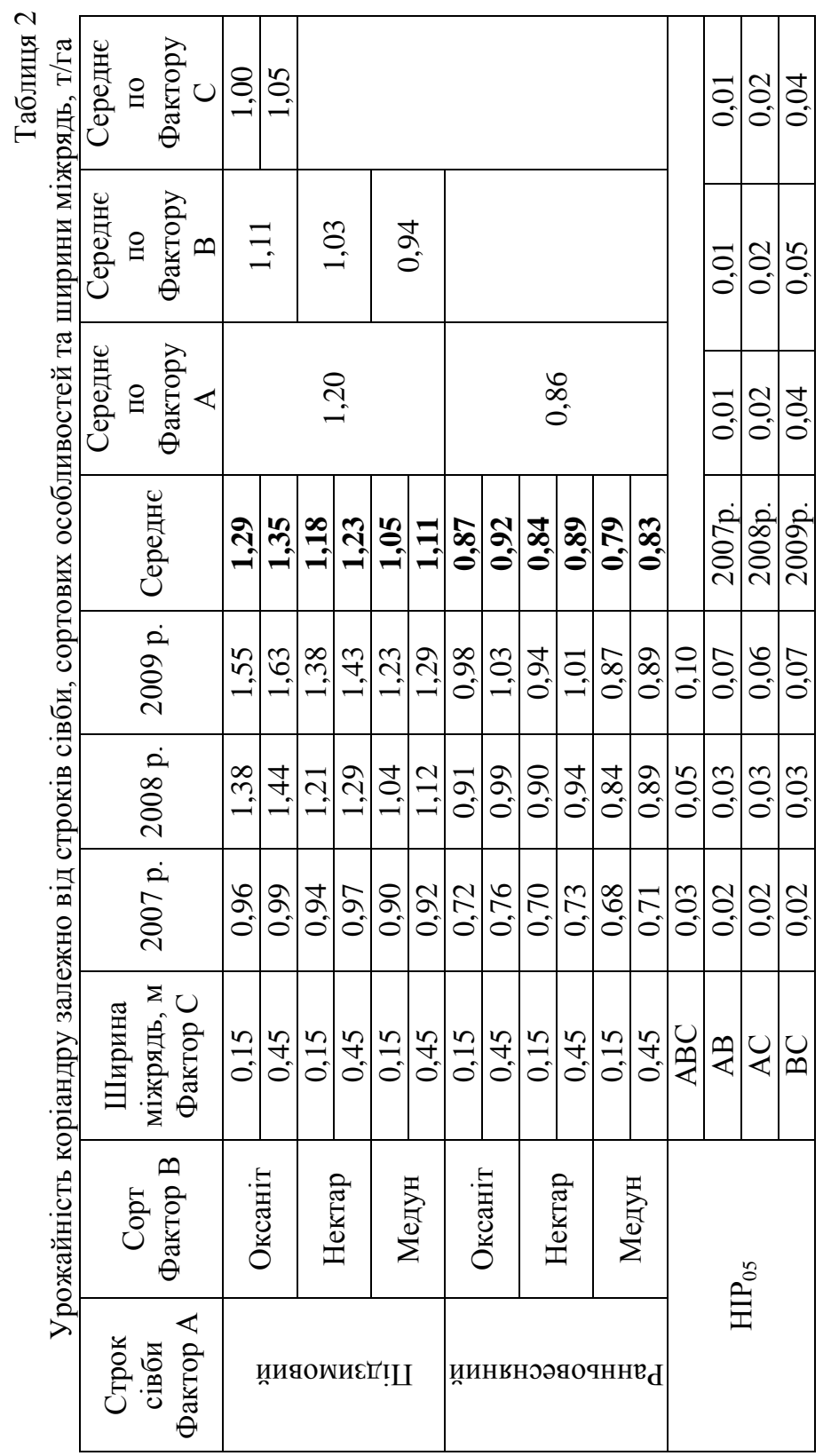




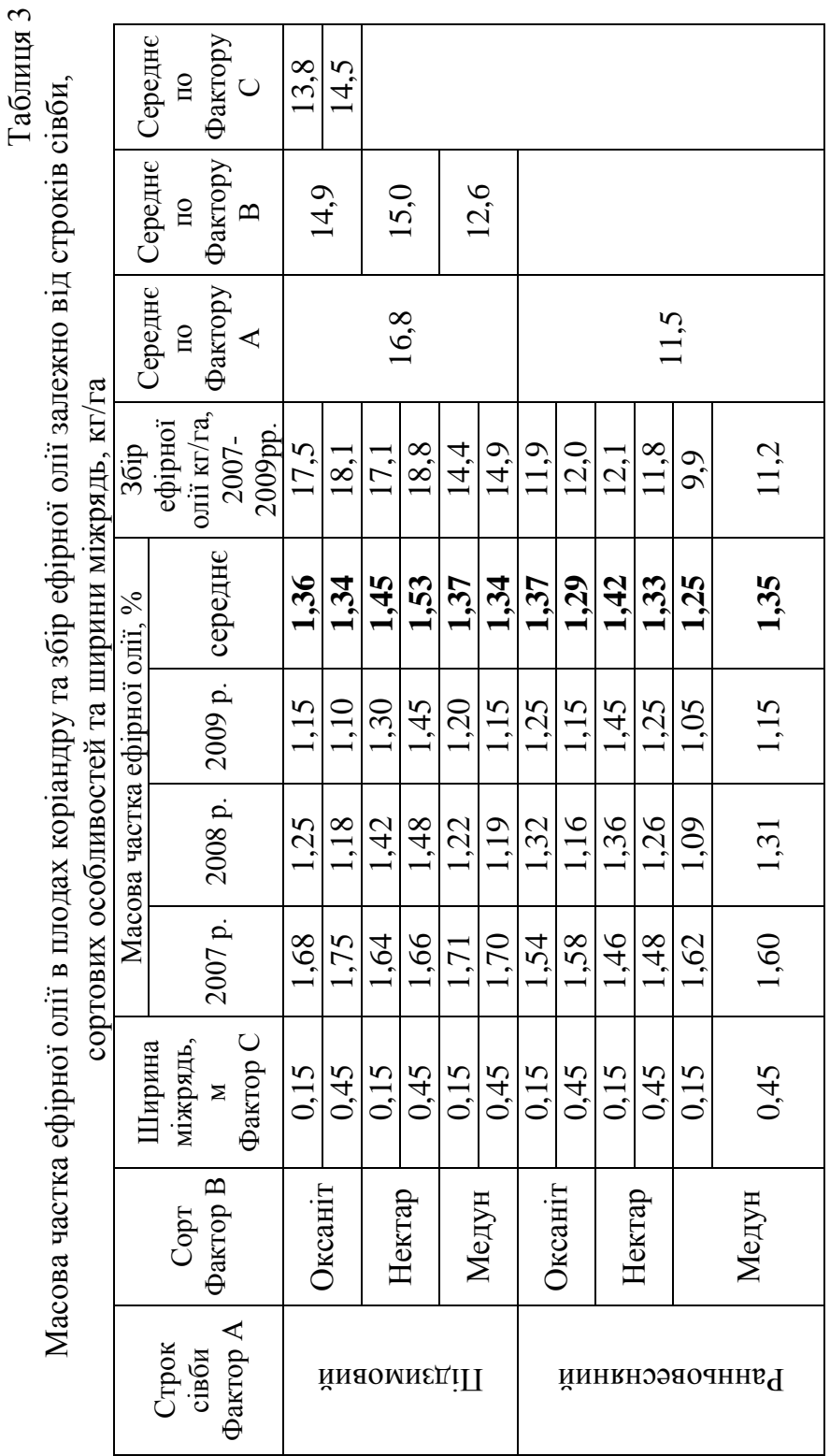


Сортові особливості впливали на масову частку ефірної олії таким чином, що в середньому за роки досліджень та по варіантах в сорту Оксаніт вона становила $-1,34 \%$, Медун - 1,33 \%, тоді як у сорту Нектар - 1,43\%.

При цьому строки сівби та ширина міжрядь не мали суттєвого впливу на масову частку ефірної олії в плодах коріандру.

Одним із основних елементів продуктивності коріандру є збір ефірної олії з 1 га. На даний показник впливали врожайність та вміст ефірної олії в плодах.

Залежно від строку сівби та сортових особливостей збір ефірної олії коливався від 9,9 до 18,8 кг/га. При підзимовому строкові сівби збір ефірної олії становив 16,8 кг/га, що на $31,5 \%$ вище, ніж при ранньовесняному (11,5 кг/га).

Значний вплив на збір ефірної олії мали сортові особливості. Так, у сорту Оксаніт він був в межах 14,9 кг/га, сорту Нектар - 15,0 кг/га, сорту Медун - 12,6 кг/га. Збільшення ширини міжрядь 3 0,15 м до 0,45 м сприяло зростанню збору ефірної олії з 13,8 до 14,5 кг/га, тобто приріст складав 0,7 кг/га. Вищий рівень даного показника був отриманий при підзимовому строкові сівби у сорту Нектар з шириною міжрядь 0,45 м і становив 18,8 кг/га, а найнижчий при ранньовесняному - у сорту Медун 3 шириною міжрядь 0,15 м $-9,9$ кг/га.

Висновки. Кращим строком сівби для коріандру в умовах північного Степу України є підзимовий, при якому отримано урожайність 1,20 т/га та збір ефірної олії - 16,8 кг/га, тоді як ранньовесняний забезпечив 0,86 т/га та 11,5 кг/га.

Вищу врожайність коріандру формував сорт Оксаніт (1,12 т/га), меншу - Нектар та Медун (1,04 та 0,95 т/га відповідно). Значний вплив на збір ефірної олії мали сортові особливості, у сорту Оксаніт він становив 14,9 кг/га, у сорту Нектар - 15,0 кг/га та у сорту Медун 12,6 кг/га.

Вищу врожайність (1,05 т/га) отримано при ширині міжрядь 0,45 м, тоді як при 0,15 м - 1,0 т/га.

\section{Список використаних джерел}

1.Наукові основи агропромислового виробництва в зоні Степу України / [Редкол.: М. В. Зубець (голова редакційної колегії) [та ін.]. - К.: Аграрна наука, 2004. - на С. 325-326.

2..Серов И. Д. Кориандр в промышленности и его возделывание / И. Д. Серов. - Саратов: Сарат. обл. изд., 1937. - 33 с.

3. Столетова Е. А. Кориандр / Е. А. Столетова -М. -Л.: Огиз-Гос. изд. с. х. колхоз.-кооп. литературы, Гидр. упр., 1931. - 68 с.

4. Гах I. С. Коріандр. / І. С. Гах, М. Т. Чудний. - Київ, -1950

5. Юркевич Ю. Коріандр - попит збільшується. / Ю. Юркевич // Пропозиція. - 2007.- №9. - C. 66-68 
Приведены обобщенные результаты исследований по изучению влияния сроков сева и сортовых особенностей на рост, развитие и продуктивность растений кориандра в условиях северной Степи Украины. Установлено, что в условиях северной Степи для получения высшей продуктивности кориандра эффективным есть проведения сева подзиму. В этих условиях получили урожайность 1,2 т/га, при ранневесеннем - 0,86 т/га. Сорт кориандра Оксанит обеспечил урожайность 1,12 т/га, Нектар - 1,04 т/га и Медун $-0,95$ т/га.

The generalized researches results on the studies of the sowing terms and the variety features on the growth, development and productivity of the coriander plants under the conditions of North Steppe of Ukraine are presented. It was established that under the conditions of North Steppe it was more effective to conduct the underwinter sowing for obtaining of the higher productivity of the coriander and the yield was $1.2 \mathrm{t} / \mathrm{ha}$, in the early spring - 0,86 t/ha. Sort of Oksanit coriander provided the yield $1.12 \mathrm{t} / \mathrm{ha}$, Nectar - 1.04 and Medun - $0.95 \mathrm{t} / \mathrm{ha}$. 